\title{
Vegetation Cover Development Resulting from Different Restoration Approaches of Exploited Mines
}

\author{
Rodrigo Studart Corrêa ${ }^{1}$ (D), Alexander Paulo do Carmo Balduíno ${ }^{1}$ (D), \\ Cláusio Tavares Viana Teza ${ }^{2}$ (D), Gustavo Macedo de Mello Baptista ${ }^{1,3}$ (D) \\ ${ }^{1}$ Programa de Pós-graduação em Ciências Ambientais - PPGCA/FUP, Universidade de Brasília - UnB, Planaltina/DF, Brasil \\ ${ }^{2}$ Universidade Católica de Brasília - UCB, Taguatinga/DF, Brasil \\ ${ }^{3}$ Programa de Pós-graduação em Geociências Aplicadas - PPGGA, Instituto de Geociências - IG, Universidade de Brasília \\ - UnB, Brasília/DF, Brasil
}

\begin{abstract}
The vegetation cover development is an essential step towards the restoration of the ecosystems. In this work, we applied remote sensing to evaluate the temporal development of vegetation cover on exploited mines revegetated with five approaches: natural regeneration, tree plantation, cultivation of trees + herbs, topsoil replacement + tree plantation, and sewage sludge incorporation into mining substrate. Results showed that the natural regeneration approach would require a secular time to provide satisfactory vegetation cover on the exploited mine. Tree plantation required fifteen years to provide $80 \%$ of vegetation cover. The use of topsoil + trees or the incorporation of sewage sludge into mining substrates achieved the fastest development of vegetation cover (2.5-5 years) and the highest percentages of revegetated surface ( $80-95 \%)$. However, the floristic composition of vegetation covers is as important as their development, and some restoration approaches are reported to stimulate weed invasion while others prevent it.
\end{abstract}

Keywords: mining, rehabilitation, restoration, NDVI, Cerrado. 


\section{INTRODUCTION}

Mining exposes surface materials called substrates that are unsuitable for the establishment and development of plants and other organisms (Dutta \& Agrawal, 2002; Silva \& Corrêa, 2010). Substrates exposed by mining act as ecological filters (Dajoz, 2005) and limit the organisms recruitment in these sites that may remain devoid of vegetation for centuries (Dutta \& Agrawal, 2002). Human intervention can accelerate the establishment of vegetation on mined substrates and sometimes shorten the process of ecological succession (Starr et al., 2013).

The rehabilitation of areas degraded by mining aims at achieving favorable topographic, edaphic and biological conditions for the reestablishment of ecological processes (Alves et al., 2007). In this sense, primary production is a key factor for ecosystem functioning (Roscher et al., 2012), and the establishment of vegetation on exploited mines is a necessary condition to promote restoration through ecological succession. The development of a vegetation cover portrays the general condition that will provide successional resources to an area undergoing recovery process (Silva et al., 2013; Starr et al., 2013). The vegetation cover development is a primary goal in mine rehabilitation because sustainable restoration requires enough vegetation cover to stabilize landforms, surfaces and exclude weeds (EPA, 2006).

Ecological restoration projects have prioritized the use of trees because they increase the structure and complexity of ecosystems and can accelerate the regeneration of degraded environments (Dutta \& Agrawal, 2002; Pinheiro et al., 2009; Starr et al., 2013). However, the time required for the growth of tree species may render them inefficient for erosion control and soil formation in the first years of plant development. Herbs offer structurally simpler environments, yet grow faster, are efficient at soil erosion control, incorporate carbon into substrates and accelerate pedogenesis (Corrêa et al., 2008; Silva et al., 2013). In the Brazilian Federal District (BFD) most restoration projects follow the silvicultural model that prevails in the country (Rodrigues et al., 2009), and exploited mines have been revegetated with trees and herbs, separately or combined in a same area (Corrêa et al., 2015; Starr et al., 2013).

The revegetation of mine surfaces requires a great amount of organic matter where topsoil is unavailable
(Corrêa et al., 2008). The incorporation of sewage sludge into mined substrates was firstly tested in the BFD in 1994 becoming routine since 2003. Such practice meets the demands for organic matter that amends inappropriate edaphic conditions. The sewage sludge produced in $\mathrm{BFD}$ is from domestic sewage treatment and presents significant levels of organic matter $\left(550 \mathrm{~g} \mathrm{~kg}^{-1}\right)$, nitrogen $\left(5.5 \mathrm{~g} \mathrm{~kg}^{-1}\right)$, phosphorus $\left(4.5 \mathrm{~g} \mathrm{~kg}^{-1}\right)$, and other nutrients in its dry matter. The spontaneous establishment of an herbaceous vegetation cover has been reported as the most evident effect after the incorporation of sewage sludge into BFD mining substrates (Silva et al., 2013).

Vegetation cover development, absence of erosion, survival and growth of planted species, recruitment of native species, and level of weed invasion are parameters used to monitor the restoration of ecosystems in Brazil (Brancalion et al., 2012). Vegetation cover or density, plant species diversity, and arthropod species diversity are the most common parameters used to evaluate ecosystem restoration throughout the world (EPA, 2006). The Surface Mining Control and Reclamation Act of 1977 is the primary law that regulates environmental effects of coal mining in the United States of America and it has established that exploited mine surfaces have to present $70 \%$ of vegetation cover within two years after the beginning of rehabilitation works (USDI, 1977).

Despite the importance of establishing a vegetation cover on mines (USDI, 1977; Alves et al., 2007; Silva \& Corrêa, 2010), there is a shortage of studies that evaluate the effect of species habit and soil fertility on development of vegetation cover on mines under restoration. Therefore, this study aimed to evaluate by using remote sensing the temporal development of vegetation cover on mines revegetated with five different approaches ( $A_{1}$ to $A_{5}$ ), based on the hypothesis that species habit and soil fertility will influence the development of vegetation cover on exploited mines.

\section{MATERIAL AND METHODS}

\subsection{Study mines}

Seven revegetated mines excavated in areas of Inceptisol (Cambissolo) and savanna vegetation (Cerrado sentido restrito) were selected in the Brazilian Federal District (BFD) for this study. The predominant BFD climate is Tropical of Savanna - Aw (Köppen-Geiger) with well-defined wet and dry seasons. Annual mean 
temperature is $21-24{ }^{\circ} \mathrm{C}$ and annual rainfall ranges from 1,200 to $1,600 \mathrm{~mm}$ and $84 \%$ of it precipitates in summer. Average annual temperature ranges from 18 to $22{ }^{\circ} \mathrm{C}$, and relative humidity varies from $12 \%$ to 85\% (Brasil, 2017).

The seven selected mines range from 15 to 67 ha and were revegetated following five different approaches, which depict the restoration practices used in the Brazilian Federal District (BFD):

$A_{1}$ - Mine left under natural regeneration (control) refers to a mine exploited in 1969 and abandoned to autogenic succession in the Brasilia National Park, where succession conditions are appropriate (Corrêa et al., 2007).

$\mathrm{A}_{2}$ - Mine revegetated with native tree species refers to a mine exploited in the 1970s in the current Riacho Fundo Wildlife Sanctuary. Terraces were built for erosion control, the exposed substrate was scarified up to $20 \mathrm{~cm}$ depth and $100 \mathrm{~L}$ tree pits were fertilized with $20 \mathrm{~L}$ of composted domestic waste and $50 \mathrm{~g}$ NPK - 4:14:8 in 2003. In the same year, the mine was revegetated with native tree species.

$\mathrm{A}_{3}$ - The same background and treatment as $\mathrm{A}_{2}$, but the mine also received waste compost $\left(20 \mathrm{~m}^{3} \mathrm{ha}^{-1}\right)$ and chemical fertilizer (1.5 $\mathrm{Mg} \mathrm{ha}^{-1} \mathrm{NPK}$ - 4:14:8) incorporated into the exposed substrate for the establishment of an herbaceous layer among trees (Silva \& Corrêa, 2008).

$A_{4}$ - Mines revegetated with the replacement of topsoil spread on the exposed surface followed by the establishment of native tree species in $100 \mathrm{~L}$ pits fertilized with $20 \mathrm{~L}$ of composted domestic waste and $50 \mathrm{~g}$ NPK - 4:14:8. One of the mine was explored in the 1960s and revegetated in 2005 and the other mine was explored 2001 and revegetated in 2003 (Pinheiro et al., 2009).

$\mathrm{A}_{5}$ - Mines spontaneously revegetated after sewage sludge application refers to two mines where sewage sludge was incorporated into the exposed substrate. The first mine was explored between 1999 and 2001 and sewage sludge (250 $\mathrm{t} \mathrm{ha}^{-1}$ at $88 \%$ moisture) was mechanically incorporated into the exposed substrate in 2002. The second mine was explored between 2000 and 2003 and received the same treatment and sewage sludge as the above mine in 2006 . The vegetation on these two mines was spontaneously established in the following years (Silva et al., 2013).

\subsection{Analysis of vegetation cover}

Vegetation cover on the study areas was evaluated by using MOD13Q1 product of the MODIS sensor (Moderate Resolution Imaging Spectroradiometer), which is embedded in the Terra platform. MOD13Q1 images of February-March from 2000 to 2013 were selected for the analysis. The choice of a fixed period for image acquisition (February-March) aimed to attenuate the effect of climatic seasonality on vegetation, since the incipient precipitation in the dry season is a limiting factor for photosynthetic activity in the Cerrado biome, especially to the herbaceous stratum (Huete et al., 2006; Becerra et al., 2009). The February-March period represents the end of the rainy season, when the highest values of photosynthetic activity and vegetation cover have been measured in the region (Silveira et al., 2008; Becerra et al., 2009).

The MOD13Q1 data are available in 16-bit format and multiplied by 0.0001 scale factor, with normalized data ranging from -1 to 1 . Negative results represent non-photosynthetically active areas in the image (NFA) and values above 0.03 represent photosynthetically active vegetation in the same image (FAV). The percentage of vegetation cover on the studied mines was calculated by the ratio of areas occupied by FAV and NFA in each MOD13Q1 image selected for this study.

\subsection{Sample collection of revegetated substrates}

Three revegetated substrate samples composed of ten sub-samples were collected from each of the seven study areas. The samples were analyzed for organic carbon by the wet combustion method (Walkley-Black) and subsequent titration with a $0.05 \mathrm{M}$ ferrous ammonium sulfate solution. Results of organic carbon were multiplied by 1.724 to estimate the organic matter (OM) concentration. Total nitrogen was evaluated by Kjeldahl distillation method. Sample $\mathrm{pH}$ was measured with a potentiometer in a 1:2.5 soil-water and $\mathrm{CaCl}_{2}$ solution. Available phosphorus (available-P) and exchangeable potassium (exchangeable-K) were extracted with Mehlich I solution $\left(0.025 \mathrm{~N} \mathrm{H}_{2} \mathrm{SO}_{4}+0.05 \mathrm{~N} \mathrm{HCl}\right)$. Available- $\mathrm{P}$ concentrations were determined in photocolorimeter at $660 \mathrm{~nm}$ and exchangeable-K concentrations in a flame atomic absorption spectrophotometer. Calcium $\left(\mathrm{Ca}^{2+}\right)$ and magnesium $\left(\mathrm{Mg}^{2+}\right)$ were extracted with $\mathrm{KCl} 1 \mathrm{~N}$ solution and their concentrations were determined in a flame atomic absorption spectrophotometer. Potential 
acidity $\left(\mathrm{H}^{+}+\mathrm{Al}^{3+}\right)$ was determined with a $0.5 \mathrm{M}$ calcium acetate buffered solution and subsequent titration with $0.05 \mathrm{M} \mathrm{NaOH}$. Cation exchange capacity (CEC at pH 7), sum of bases (S), and percentage base saturation (V\%) of samples were calculated based on the analytical results (Table 1), according to EMBRAPA (1997).

\subsection{Data handling}

The vegetation cover values were inserted on ordinate axis of a graph, time elapsed since mine revegetation works was inserted on abscissa axis, and regression models were tested using Origin 9 Pro software. Responses to the treatments given to the study areas were adjusted to regression equations (Corrêa et al., 2008). Maximum values of vegetation cover on each area were obtained from functions described by regressions. The relation between substrate fertility (Table 1) and maximum vegetation cover was also tested by regressions.

Fertility parameters of revegetated substrates (Table 1) were normalized (Equation 1), standardized (Equation 2) (Legendre \& Legendre, 1998), and submitted to Principal Component Analysis in Origin 9 Pro software as follow:

$\mathrm{Yi}^{\prime}=\log (\mathrm{Yi}+1)$

$\mathrm{Zi}=\left(\mathrm{Yi}^{\prime}-\overline{\mathrm{Y}}^{\prime}\right) / \mathrm{sy}^{\prime}$

where

$\mathrm{Zi}$ is the $\mathrm{z}$-score (dimensionless variable);

$\bar{Y}^{\prime}$ is the variable normalized mean;

sy' is the variable standard deviation for the normalized mean

\section{RESULTS}

After 44 years of natural regeneration, plants that recruited on the exploited mine in the Brasilia National Park $\left(A_{1}\right)$ covered $35 \%$ of its surface. Vegetation cover development followed a linear model during the evaluated period, with $0.8 \%$ cover increase a year (Table 1; Figure 1). The employed revegetation approaches $\left(A_{2}, A_{3}, A_{4}\right.$ and $\left.A_{5}\right)$ significantly increased the establishment of plants on mines, and the temporal development of vegetation cover evolved from linear regeneration model to exponential models over a decade (Figure 1).

Vegetation cover development and maximum percentage of surface covered by plants varied according to the revegetation approach applied to the mines. Topsoil spread on exposed surfaces + tree plantation $\left(\mathrm{A}_{4}\right)$ provided the highest percentage of vegetation cover among the evaluated treatments, reaching 95\% in seven years. The incorporation of sewage sludge into mining substrates $\left(\mathrm{A}_{5}\right)$ provided the fastest vegetation development, stabilizing in $80-90 \%$ cover within 2 to 4 years. Similarly, the cultivation of an herbaceous layer among trees $\left(\mathrm{A}_{3}\right)$ provided a rapid vegetation cover on mines in the first two years of plant development. However, this coverage stabilized at $80 \%$ after a decade of plant development. The exclusive use of trees as restoration technique $\left(\mathrm{A}_{2}\right)$ resulted in $65 \%$ of vegetation coverage after ten years of plant development.

The rehabilitation approaches applied to the mines also resulted in different levels of substrate fertility (Table 2). The lowest values of the analyzed parameters were measured in the area left under

Table 1. Temporal responses of vegetation cover to the revegetation approaches employed in the study mines.

\begin{tabular}{|c|c|c|c|}
\hline Revegetation approach & $\begin{array}{c}\text { Equation } \\
\text { Vegetation cover }\end{array}$ & $\mathbf{R}^{2}$ & $\begin{array}{l}\text { Time up to } 80 \% \\
\text { vegetation cover }\end{array}$ \\
\hline$A_{1}$ - Natural regeneration (control) & $\hat{\mathrm{Y}}=5.25+0.79 \mathrm{X}$ & $0.90^{* *}$ & 94 years \\
\hline $\mathrm{A}_{2}$ - Tree plantation & $\hat{\mathrm{Y}}=65.54-60.65 \mathrm{e}^{-0.77 \mathrm{x}}$ & $0.86^{*}$ & 15 years \\
\hline $\mathrm{A}_{3}$ - Tree plantation + herbs & $\hat{\mathrm{Y}}=79.01-73.95 \mathrm{e}^{-1.92 \mathrm{X}}$ & $0.99^{* *}$ & 6 years \\
\hline $\mathrm{A}_{4}$ - Topsoil replacement + tree plantation & $\hat{\mathrm{Y}}=94.56-81.49 \mathrm{e}^{-0.69 \mathrm{x}}$ & $0.99^{* *}$ & 2.5 years \\
\hline $\mathrm{A}_{4}$ - Topsoil replacement + tree plantation & $\hat{\mathrm{Y}}=97.64-93.34 \mathrm{e}^{-0.45 \mathrm{X}}$ & $0.95^{\star *}$ & 3.8 years \\
\hline $\begin{array}{l}A_{5}-\text { Sewage sludge incorporation into } \\
\text { substrate + natural regeneration }\end{array}$ & $\hat{\mathrm{Y}}=96.76-90.21 \mathrm{e}^{-0.35 \mathrm{x}}$ & $0.83^{*}$ & 4.9 years \\
\hline $\begin{array}{l}A_{5}-\text { Sewage sludge incorporation into } \\
\text { substrate + natural regeneration }\end{array}$ & $\hat{Y}=81.15-67.39 e^{-1.10 x}$ & $0.97^{\star *}$ & 3.8 years \\
\hline
\end{tabular}

${ }^{*}$ Significant at $\mathrm{p}<0.05 ;{ }^{*}$ Significant at $\mathrm{p}<0.01$. 


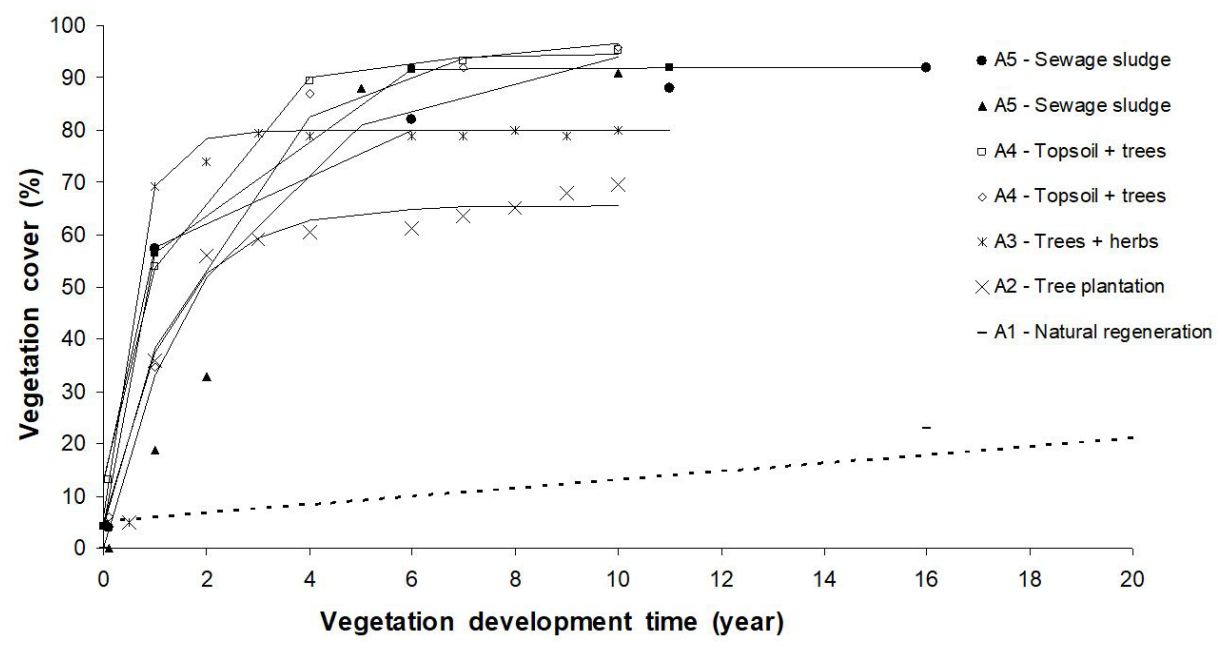

Figure 1. Vegetation cover development on the study mines as a function of revegetation approach and time.

Table 2. Chemical parameters analyzed in substrates of the revegetated mines.

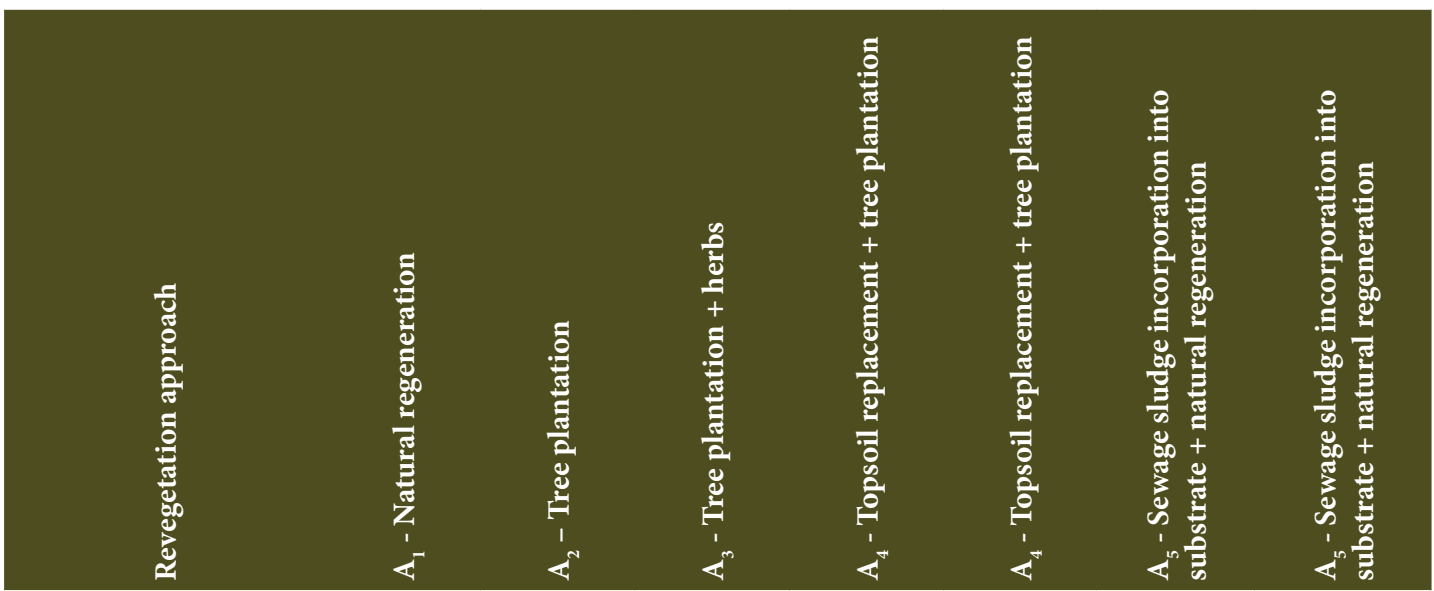

Parameter

\begin{tabular}{|c|c|c|c|c|c|c|c|}
\hline Organic matter $\left(\mathrm{g} \mathrm{kg}^{-1}\right)$ & $0.8 \pm<0.1$ & $20.3 \pm 0.6$ & $44.7 \pm 0.8$ & $11.8 \pm 0.1$ & $20.8 \pm 0.3$ & $57.1 \pm 0.3$ & $79.7 \pm 0.5$ \\
\hline $\mathrm{pH}\left(\mathrm{H}_{2} \mathrm{O}\right)$ & $5.4 \pm 0.2$ & $6.8 \pm 0.1$ & $6.3 \pm 0.3$ & $5.6 \pm 0.2$ & $5.3 \pm 0.2$ & $5.1 \pm 0.1$ & $5.1 \pm 0.3$ \\
\hline $\mathrm{pH}\left(\mathrm{CaCl}_{2}\right)$ & $4.9 \pm 0.1$ & $6.2 \pm 0.3$ & $5.7 \pm 0.2$ & $5.2 \pm 0.3$ & $4.9 \pm<0.1$ & $5.0 \pm 0.1$ & $4.9 \pm<0.1$ \\
\hline Total-N ( $\left.\mathrm{g} \mathrm{kg}^{-1}\right)$ & $0.1 \pm<0.1$ & $1.4 \pm 0.2$ & $2.9 \pm 0.2$ & $0.9 \pm<0.1$ & $1.3 \pm 0.1$ & $3.5 \pm 0.2$ & $4.6 \pm 0.3$ \\
\hline Available-P $\left(\mathrm{mg} \mathrm{kg}^{-1}\right)$ & $0.1 \pm<0.1$ & $2.2 \pm 0.1$ & $3.7 \pm 0.3$ & $1.4 \pm 0.2$ & $1.6 \pm 0.1$ & $1,380.3 \pm 10.3$ & $1,055.0 \pm 7.1$ \\
\hline $\mathrm{CEC}\left(\mathrm{cmolc} \mathrm{kg}^{-1}\right)$ & $2.3 \pm 0.4$ & $3.1 \pm 0.2$ & $5.9 \pm 0.2$ & $12.0 \pm 0.5$ & $7.8 \pm 0.3$ & $23.8 \pm 4.3$ & $18.5 \pm 1.5$ \\
\hline Base saturation (\%) & $30.4 \pm 4.3$ & $77.7 \pm 6.1$ & $62.7 \pm 2.3$ & $9.0 \pm 0.3$ & $8.0 \pm 1.3$ & $57.3 \pm 3.2$ & $47.7 \pm 3.8$ \\
\hline Exchangeable-K (cmolc kg-1) & $0.1 \pm<0.1$ & $0.2 \pm<0.1$ & $1.3 \pm<0.1$ & $0.6 \pm 0.2$ & $0.3 \pm<0.1$ & $2.8 \pm 0.3$ & $2.5 \pm 0.1$ \\
\hline $\mathrm{Ca}^{2+}+\mathrm{Mg}^{2+}\left(\mathrm{cmolc} \mathrm{kg}^{-1}\right)$ & $0.6 \pm<0.1$ & $2.2 \pm 0.2$ & $2.4 \pm 0.2$ & $0.5 \pm<0.1$ & $0.3 \pm<0.1$ & $10.8 \pm 1.1$ & $6.3 \pm 0.3$ \\
\hline $\mathrm{S}\left(\mathrm{cmolc} \mathrm{kg}^{-1}\right)$ & $0.7 \pm 0.1$ & $2.4 \pm 0.2$ & $3.7 \pm 0.2$ & $1.1 \pm 0.1$ & $0.6 \pm 0.2$ & $13.6 \pm 2.1$ & $8.8 \pm 2.3$ \\
\hline $\mathrm{I}^{+}+\mathrm{Al}^{3+}\left(\mathrm{cmolc} \mathrm{kg}^{-1}\right)$ & $1.6 \pm 0.1$ & $0.7 \pm<0.3$ & $2.2 \pm 0.1$ & $10.9 \pm 0.9$ & $7.2 \pm 1.2$ & $10.2 \pm 1.8$ & $9.7 \pm 0.9$ \\
\hline
\end{tabular}

Mean \pm standard deviation.

natural regeneration $\left(A_{1}\right)$ and the highest values were measured in areas that received sewage sludge as source of organic matter and plant nutrients - $\mathrm{A}_{5}$ (Table 2). The Principal Component Analysis (PCA) of measured fertility parameters isolated the mine left under natural regeneration $\left(A_{1}\right)$ from the other restoration approaches $\left(A_{2}, A_{3}, A_{4}, A_{5}\right)$ opposing itself to the measured fertility parameters (Figure 2). Mines revegetated with sewage 


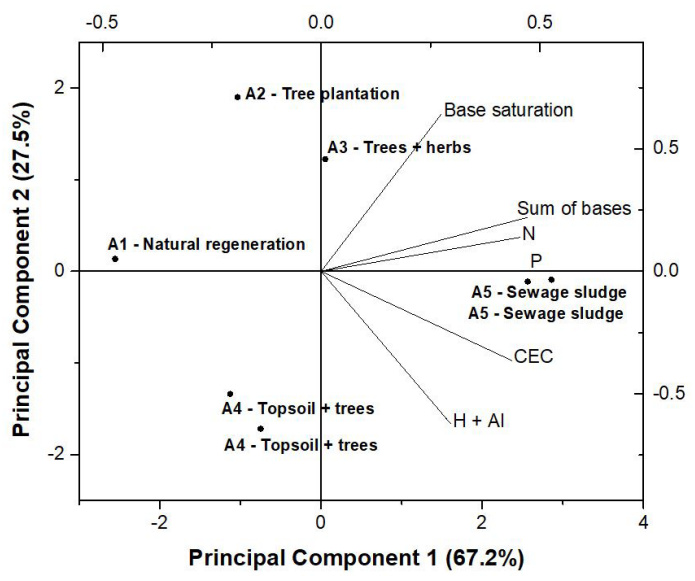

Figure 2. Principal Component Analysis (PCA) of analyzed parameters in revegetated substrates from the study mines.

sludge $\left(A_{5}\right)$ were closely associated with the measured concentrations of available- $\mathrm{P}$ and cation exchange capacity (CEC) (Figure 2). Mine surfaces that received topsoil $\left(\mathrm{A}_{4}\right)$ apposed to mines where trees and herbs were grown on chemically and organically fertilized substrates $\left(\mathrm{A}_{2}\right.$ and $\left.\mathrm{A}_{3}\right)$ (Table 2; Figure 2). Attempts to relate edaphic parameters and vegetation cover were successful in establishing that the maximum vegetation cover in the study mines was a function of five out the eleven edaphic analyzed parameters (Max. Cover $=32.7+1.3 \mathrm{OM}+5.6 \mathrm{CEC}-0.03 \mathrm{P}-8.2 \mathrm{Mg}-25.4 \mathrm{~K}$; $\mathrm{R}^{2}=0.98$ and $\left.\mathrm{p}<0.05\right)$

\section{DISCUSSION}

The ecological succession in terrestrial ecosystems demands stable landscapes (Dajoz, 2005) and the development of a vegetation cover is one of the most effective measures for stabilizing mined surfaces (Brancalion et al., 2012). Erosion control facilitates the course of succession (EPA, 2006; Reis et al., 2010) and an $80 \%$ vegetation cover is considered appropriate to control rainfall erosion and stabilize landscapes in most areas undergoing restoration in the tropics (Brancalion et al., 2012). In this work, the mine left under natural regeneration $\left(\mathrm{A}_{1}\right)$ would require almost a century for its surface to reach $80 \%$ vegetation cover (Table 1; Figure 1). Tree plantation over the exposed substrate $\left(\mathrm{A}_{2}\right)$ shortened this time to fifteen years, and herb cultivation conjugated with trees $\left(\mathrm{A}_{3}\right)$ on the same mine was able to further reduce this time to six years. Topsoil replacement + tree plantation $\left(\mathrm{A}_{4}\right)$ achieved $80 \%$ vegetation cover on the exposed surfaces within 2.5 - 4 years and mines where sewage sludge was incorporated into the exposed surface $\left(\mathrm{A}_{5}\right)$ required from 4 to 5 years to reach this same vegetation cover percentage (Table 1; Figure 1).

Restoration success largely depends on the adopted rehabilitation practices (Pivello, 2011) and the development of a vegetation cover is the result of establishment and growth of plants able to colonize an area under restoration (Starr et al., 2013; Corrêa et al., 2015). The long-term demanded for the vegetation cover development on the mine located in the Brasília National Park - $\mathrm{A}_{1}$ (Table 1; Figure 1), where diaspores are abundant, portrays the adverse conditions of the mined surface. Increases in species richness and plant biomass are necessary for the development of an ecosystem (Starr et al., 2013) but a few Cerrado species are able to recruit on exploited mines (Corrêa et al., 2007), where chemical, physical, and biological conditions cannot support live forms (Corrêa \& Bento, 2010).

The vegetation cover development on mines rehabilitated with trees - $A_{2}$ (Table 1; Figure 1) is not a consequence of the growth of these specimens alone (Starr et al., 2013). Trees have a significant role on plant recruitment and ecological succession because they ameliorate the microclimate, attract seed dispersers, increase vegetation structure, and provide structural complexity to the environment (Kumar et al., 2010). Also, the excavation and fertilization of tree pits create suitable substrates for the germination and colonization of herbs and shrubs that spontaneously reach these pits and grow on the exposed surface (Silva \& Corrêa, 2008). Herbs grow fast, improve the edaphic environment (Corrêa \& Bento, 2010) and may facilitate the establishment of other plants on revegetated mines (Kumar et al., 2010; Silva \& Corrêa, 2010; Starr et al., 2013). The establishment of herbs on exploited mines in the Cerrado biome has been defended as a restoration protocol because many species of native herbs are well adapted to the adverse conditions of excavated substrates (Martins et al., 2011).

The mines where topsoil was spread on exposed surface presented the highest percentage of vegetation 
cover among the evaluated revegetation approaches 95\% (Table 1; Figure 1). Topsoils present the elements necessary for the spontaneous establishment of plants, such as organic matter, nutrients, seeds, and soil microorganisms (Silva \& Corrêa, 2010). These elements allow a rapid recolonization of degraded environments by herbs (Ávila et al., 2013), fundamental for the process of ecological succession (Araújo et al., 2004; Martins et al., 2011).

The incorporation of high rates of sewage sludge (250 $\mathrm{Mg} \mathrm{ha}^{-1}, 88 \%$ moisture) into mining substrates has created edaphic environments quickly colonized by plants (Silva et al., 2013) as a result of the high concentrations of organic matter and available nutrients from this residue (Paula et al., 2011). The substrate fertility level built with sewage sludge (Table 2) is sufficient for the establishment of dense layers of plants on exploited mines (Corrêa et al., 2008). Besides the importance of vegetation cover, plant biomass accumulation is essential for the restoration of ecosystems because plants supply other trophic levels of the food chain with matter, energy, and shelter (EPA, 2006; Dutta \& Agrawal, 2002; Becerra et al., 2009).

Increase edaphic fertility by mixing sewage sludge into substrates has shown to be an effective approach to quickly providing a satisfactory vegetation cover on exploited mines (Table 1; Figure 1). But the floristic composition recruited in these mines may lead succession towards an ecosystem dissimilar to the native one due to the allochthonous species that dominate these ambient (Silva et al., 2013). Alien species invasion is a frequent concern in the course of ecosystem restoration (Sampaio \& Schmidt, 2013) and most invasive plant species are very efficient on the use of nutrients available in soils (Pivello, 2011). Even in native formations of Cerrado, soil application of $\mathrm{N}$ and $\mathrm{P}$ favors the dominance of invasive grasses over autochthonous species (Bustamante et al., 2012; Lannes et al., 2015).

The restoration of vegetation cover on exploited mines demands substrate rehabilitation (Figure 1), but barren rehabilitated substrates in the BFD have housed invasive grasses rather than Cerrado species (Pinheiro et al., 2009; Silva et al., 2013; Starr et al., 2013). The cultivation of some herbs on rehabilitated substrates is capable of avoiding the dominance of invasive species that do not freely proliferate in occupied spaces and niches (Pathikonda et al., 2009). In this sense, the vegetation cover from tree plantation + herbs $\left(\mathrm{A}_{3}\right)$ was reported to be more diverse and less infested by allochthonous species than the vegetation cover from tree plantation only $\left(\mathrm{A}_{2}\right)$, where empty spaces among trees allowed weed invasion (Starr et al., 2013).

Vegetation cover, plant biomass, and species richness are related attributes (Duffy et al., 2017), and the sowing of rich mixtures of herbaceous species on barren soils has long positive effects on biomass productivity and plant diversity (Weidlich et al., 2017). Diverse plant communities are more resistant to weed invasion, and the arrival order of species in a site has strong effects on the floristic composition and functioning of a plant community (Weidlich et al., 2017). Therefore, any revegetation approach $\left(A_{2}-A_{5}\right)$ of exploited mines should primarily seal the rehabilitated substrate with a diverse mixture of fast-growing autochthonous species because priority and diversity effects are powerful tools for ecological restoration (Starr et al., 2013; Weidlich et al., 2017).

\section{CONCLUSION}

Plant cover development and maximum vegetation cover on exploited mines varied according to the employed species habit (tree or herb) and the level of substrate fertility.

Topsoil replacement + tree plantation $\left(\mathrm{A}_{4}\right)$ was the approach that combined the shortest time of vegetation cover development and the highest percentage of surface covered by plants.

Topsoil replacement + tree plantation $\left(\mathrm{A}_{4}\right)$ and the incorporation of sewage sludge into mining substrates $\left(A_{5}\right)$ promoted the establishment of plant covers between 10 and $15 \%$ higher than the combined cultivation of herbs and trees $\left(A_{3}\right)$ on mined surfaces.

The floristic composition of vegetation covers is as important as their development, and autochthonous species shall dominate plant communities on rehabilitated substrates for the sake of a sound ecological succession.

\section{ACKNOWLEDGEMENTS}

The authors thank the referees who improved the manuscript quality. 


\section{SUBMISSION STATUS}

Received: 04 nov., 2017

Accepted: 24 jan., 2018

\section{CORRESPONDENCE TO}

\section{Rodrigo Studart Corrêa}

Programa de Pós-graduação em Ciências

Ambientais - PPGCA/FUP, Universidade de

Brasília - UnB, CP 04401, CEP 70842970,

Planaltina, DF, Brasil

e-mail: rodmanga@yahoo.com.br

\section{FINANCIAL SUPPORT}

Conselho Nacional de Desenvolvimento Científico e Tecnológico - CNPq, (Grant / Award Number: 'Edital Universal 14/2014').

\section{REFERENCES}

Alves MC, Suzuki LGAS, Suzuki LEAS. Densidade do solo e infiltração de água como indicadores da qualidade física de um latossolo vermelho distrófico em recuperação. Revista Brasileira de Ciência do Solo 2007; 31(4): 617-625. http://dx.doi.org/10.1590/S0100-06832007000400002.

Araújo MM, Longhi SJ, Barros PLC, Brena DA. Caracterização da chuva de sementes, banco de sementes do solo e banco de plântulas em Floresta Estacional Decidual ripária, Cachoeira do Sul, RS, Brasil. Scientia Forestalis 2004; 11(4): 128-141.

Ávila AL, Araújo MM, Gasparin E, Longhi SJ. Mecanismos de regeneração natural em remanescentes de Floresta Ombrófila Mista, RS, Brasil. Cerne 2013; 19(4): 621-628. http://dx.doi.org/10.1590/S0104-77602013000400012.

Becerra JAB, Shimabukuro YE, Alvalá RCS. Relação do padrão sazonal da vegetação com a precipitação na região de Cerrado da Amazônia Legal, usando índices espectrais de vegetação. Revista Brasileira de Meteorologia 2009; 24(2): 125-134. http://dx.doi.org/10.1590/S010277862009000200002 .

Brancalion PHS, Viani RAG, Rodrigues RR, Gandolfi S. Avaliação e monitoramento de áreas em processo de restauração. In: Martins SV, editor. Restauração ecológicas de ecossistemas degradados. Viçosa: Universidade Federal de Viçosa; 2012.

Brasil. Ministério da Agricultura, Pecuária e Abastecimento Instituto Nacional de Meteorologia - INMET. Distrito Federal [online]. Brasília: INMET; 2017 [cited 2017 aug 18]. Available from: http://www.inmet.gov.br
Bustamante MMC, Brito DQ, Kozovits AR, Luedemann G, Mello TRB, Siqueira Pinto A et al. Effects of nutrient additions on plant biomass and diversity of the herbaceoussubshrub layer of a Brazilian savanna (Cerrado). Plant Ecology 2012; 213(5): 795-808. http://dx.doi.org/10.1007/ s11258-012-0042-4.

Corrêa RS, Baptista GMM, Balduíno APC, Silva LCR. Eficiência agronômica de dois resíduos orgânicos na revegetação do horizonte C de um Latossolo Vermelho. Revista Ciência Agronômica 2008; 39(4): 503-510.

Corrêa RS, Bento MAB. Qualidade do substrato minerado de uma área de empréstimo revegetada no Distrito Federal. Revista Brasileira de Ciência do Solo 2010; 34(4): 1435-1443. http://dx.doi.org/10.1590/S0100-06832010000400039.

Corrêa RS, Mélo B Fo, Baptista GMM. Avaliação fitossociológica da sucessão autogênica em áreas mineradas no Distrito Federal. Cerne 2007; 13(4): 406-415.

Corrêa RS, Mélo B Fo, Pinheiro CQ, Santos PF. Floristic wood composition of revegetated mining sites in the Brazilian Federal District. Bioscience Journal 2015; 31(3): 908-922. http://dx.doi.org/10.14393/BJ-v31n3a2015-22986.

Dajoz R. Ecologia geral. Porto Alegre: Artmed; 2005.

Duffy JE, Godwin CM, Cardinale BJ. Biodiversity effects in the wild are common and as strong as key drivers of productivity. Nature 2017; 549(7671): 261-264. http:// dx.doi.org/10.1038/nature23886. PMid:28869964.

Dutta RK, Agrawal M. Effect of tree plantations on the soil characteristics and microbial activity of coal mine spoil land. Tropical Ecology 2002; 43(2): 315-324.

Empresa Brasileira de Pesquisa Agropecuária - EMBRAPA. Manual de métodos de análise de solo. Rio de Janeiro; 1997.

Environmental Protection Authority - EPA. Guidance for the Assessment of Environmental Factors in accordance with the Environmental Protection Act 1986. Western Australia: EPA; 2006. (Rehabilitation of Terrestrial Ecosystems; no. 6).

Huete AR, Didan K, Shimabukuro YE, Ratana P, Saleska SR, Hutyra LR et al. Amazon rainforests green-up with sunlight in dry season. Geophysical Research Letters 2006; 33(L06405): 1-4. http://dx.doi.org/10.1029/2005GL025583.

Kumar A, Raghuwanshi R, Upadhyay RS. Arbuscular mycorrhizal technology in reclamation and revegetation of coal mine spoils under various revegetation models. Engineering 2010; 2(09): 683-689. http://dx.doi.org/10.4236/ eng.2010.29088.

Lannes LS, Bustamante MMC, Edwards PJ, Olde Venterink H. Native and alien herbaceous plants in Brazilian Cerrado are (co-) limited by different nutrients. Plant and Soil 2015; 400(1-2): 231-243. http://dx.doi.org/10.1007/ s11104-015-2725-9.

Legendre P, Legendre L. Numerical ecology: developments in environmental modelling. Amsterdam: Elsevier; 1998. 
Martins CR, Hay JDV, Walter BMT, Proença CEB, Vivaldi LJ. Impacto da invasão e do manejo do capim-gordura (Melinis minutiflora) sobre a riqueza e biomassa da flora nativa do Cerrado sentido restrito. Revista Brasileira de Botanica. Brazilian Journal of Botany 2011; 34(1): 73-90. http://dx.doi.org/10.1590/S0100-84042011000100008.

Pathikonda S, Ackleh AS, Hasenstein KH, Mopper S. Invasion, disturbance, and competition: modeling the fate of coastal plant populations. Conservation Biology 2009; 23(1): 164-173. http://dx.doi.org/10.1111/j.15231739.2008.01073.x. PMid:18950474.

Paula RA, Corrêa RS, Cotta TP. Lixiviação de nitrato de um substrato minerado tratado com lodo de esgoto doméstico. Bragantia 2011; 70(1): 104-112. http://dx.doi. org/10.1590/S0006-87052011000100016.

Pinheiro CQ, Corrêa RS, Silveira IM, Jesus RS, Jorge RRA. Análise fitossociológica do estrato arbóreo de uma cascalheira revegetada no Distrito Federal. Cerne 2009; 15(2): 205-214

Pivello VR. Invasões biológicas no Cerrado brasileiro: efeitos da introdução de espécies exóticas sobre a biodiversidade. Ecologia. Info 33 [online]. 2011 [cited 2017 Dec 5]. Available from: http://ecologia.info/cerrado.htm

Reis A, Bechara FC, Tres DR. Nucleation in tropical ecological restoration. Scientia Agrícola 2010; 67(2): 244250. http://dx.doi.org/10.1590/S0103-90162010000200018.

Rodrigues RR, Lima RAF, Gandolfi S, Nave AG. On the restoration of high diversity forests: 30 years of experience in the Brazilian Atlantic Forest. Biological Conservation 2009; 142(6): 1242-1251. http://dx.doi.org/10.1016/j. biocon.2008.12.008.

Roscher C, Schumacher J, Gubsch M, Lipowsky A, Weigelt A, Buchmann $\mathrm{N}$ et al. Using plant functional traits to explain diversity-productivity relationships. PLoS One 2012; 7(5): e36760. http://dx.doi.org/10.1371/journal. pone.0036760. PMid:22623961.
Sampaio AB, Schmidt IB. Espécies exóticas invasoras em unidades de conservação federais do Brasil. Biodiversidade Brasileira 2013; 3(2): 32-49.

Silva LCR, Corrêa RS, Doane TA, Pereira EIP, Horwath WR. Unprecedented carbon accumulation in mined soils: the synergistic effect of resource input and plant species invasion. Ecological Applications 2013; 23(6): 1345-1356. http://dx.doi.org/10.1890/12-1957.1. PMid:24147407.

Silva LCR, Corrêa RS. Sobrevivência e crescimento de seis espécies arbóreas submetidas a quatro tratamentos em área minerada no Cerrado. Revista Árvore 2008; 32(4): 731-740. http://dx.doi.org/10.1590/S0100-67622008000400015.

Silva LCR, Corrêa RS. Evolução da qualidade do substrato de uma área minerada no Cerrado revegetada com Stylosanthes spp. Revista Brasileira de Engenharia Agrícola e Ambiental 2010; 14(8): 835-841. http://dx.doi. org/10.1590/S1415-43662010000800007.

Silveira EMO, Carvalho LMT, Acerbi-Júnior FW, Mello JM. The assesssment of vegetation seasonal dynamics using multitemporal NDVI and EVI images derived from MODIS. Cerne 2008; 14(2): 177-184. http://dx.doi. org/10.1109/MULTITEMP.2007.4293049.

Starr CR, Corrêa RS, Filgueiras TS, Hay JDV, Santos PF. Plant colonization in a gravel mine revegetated with Stylosanthes spp. in a Neotropical savanna. Landscape and Ecological Engineering 2013; 9(1): 189-201. http:// dx.doi.org/10.1007/s11355-012-0196-1.

United States Department of the Interior - USDI. Office of Surface Mining Reclamation and Enforcement. Surface Mining Control and Reclamation Act (SMCRA) PL 95-87 [online]. Washington: USDI; 1977 [cited 2017 Dec 5]. Available from: https://www.osmre.gov/LRG.shtm

Weidlich EW, von Gillhaussen P, Delory BM, Blossfeld S, Poorter H, Temperton VM. The importance of being first: exploring priority and diversity effects in a grassland field experiment. Frontiers in Plant Science 2017; 7(1): 2008. http://dx.doi.org/10.3389/fpls.2016.02008. PMid:28119707. 